\title{
Food web interactions along seagrass-coral reef boundaries: effects of piscivore reductions on cross-habitat energy exchange
}

\author{
John F. Valentine ${ }^{1,2, *}$, Kenneth L. Heck Jr. ${ }^{1,2}$, Derrick Blackmon ${ }^{1,2}$, \\ Margene E. Goecker ${ }^{1,2}$, Juliet Christian ${ }^{1,2}$, Ryan M. Kroutil ${ }^{1,2}$, Kevin D. Kirsch ${ }^{3}$, \\ Bradley J. Peterson ${ }^{4}$, Mike Beck ${ }^{5}$, Mathew A. Vanderklift ${ }^{6,7}$ \\ ${ }^{1}$ Dauphin Island Sea Laboratory, University of South Alabama, 101 Bienville Boulevard, Dauphin Island, \\ Alabama 36528-0369, USA \\ ${ }^{2}$ Department of Marine Science, University of South Alabama, Mobile, Alabama 36688, USA \\ ${ }^{3}$ NOAA Damage Assessment Center, PO Box 500368, Marathon, Florida 33050, USA \\ ${ }^{4}$ Marine Science Division, Southampton College, Southampton, New York 11968-4198, USA \\ ${ }^{5}$ The Nature Conservancy, 100 Shaffer Road, University of California, Santa Cruz, California 95060, USA \\ ${ }^{6}$ CSIRO Marine Research, Underwood Avenue, Floreat, Western Australia, Australia \\ ${ }^{7}$ Centre for Ecosystem Management, Edith Cowan University, 100 Joondalup Drive, Joondalup, Western Australia, Australia
}

\begin{abstract}
Although early studies qualitatively documented the importance of cross-habitat energy transfers from seagrasses to coral reefs, such exchanges have yet to be quantified. Empirical evidence suggests that grazing by reef-associated herbivores along the coral reef-seagrass interface can be intense (e.g. conspicuous presence of bare-sand 'halos' surrounding coral reefs). This evidence must be interpreted with caution, however, as most of it comes from areas that have experienced sustained, intense overfishing. To quantify the impacts of piscivore removal on cross-habitat energy exchange at the coral reef-seagrass interface, we compared grazing intensity along fished and notake reefs in the upper and lower Florida Keys. Using visual census techniques and direct measures of seagrass grazing, we documented the impacts of piscivore density on herbivory along the seagrass-coral reef interface. Grazing rates were greater than observed seagrass (Thalassia testudinum) production near reefs in the upper Keys, but less than $48 \%$ of production in the lower Keys. Analyses showed that these large differences were not related to regional differences in either herbivore density or species composition. Seagrass biomass was also lower near reefs in the upper Keys, where estimates of grazing were highest. Piscivores were dominated by transient predators (jacks and barracudas) whose densities varied with region and distance from reef, but not with protection from fishing. A nonsignificant negative correlation between great barracuda density and leaf losses from tethered shoots, coupled with the greater abundances of larger grazers near reefs, suggests that predation risk, rather than direct reductions in density, may limit grazers to intense feeding on seagrasses adjacent to reefs in the upper Keys. The large-scale variation in grazing intensity illustrates the need for more detailed quantifications of energy exchanges along the seagrass-coral reef boundary.
\end{abstract}

KEY WORDS: Edge effects $\cdot$ Herbivory $\cdot$ Overfishing $\cdot$ Parrotfish $\cdot$ Spatial subsidies $\cdot$ Trophic transfer

\section{INTRODUCTION}

Cross-habitat exchanges of nutrients and energy (i.e. spatial subsidies) can be of great importance, especially in areas where in situ primary production is either low or unavailable to higher-order consumers (Polis \& Strong 1996). In some cases, these exchanges are so strong that they can allow consumers to exist at much higher densities than would be possible if they relied solely on autochthonous production (e.g. Hilder- 
brand et al. 1999, Nakano \& Murakami 2001). While ecologists working at the terrestrial-aquatic interface have quantified the strength of such exchanges (Powers 2001), few have done so for marine environments (Cadenasso et al. 2003).

Despite recent investigations of the importance of exogenous inputs of nutrients to coral reef food webs (Leichter et al. 2003), most researchers adhere to the view that reef communities are closed entities characterized by tight recycling processes (Hatcher 1997). Although early evidence qualitatively documented the importance of cross-habitat energy transfer from seagrasses to coral reefs (see review by Valentine \& Duffy 2006), such exchanges have yet to be quantified. Instead, most studies rely on descriptions of poorly resolved food webs (Link 2002, Dunne et al. 2004), static measures of biomass within trophic compartments, or mass balance approximations of the nutritional requirements of higher-order consumers to estimate production at the base of reef food webs. Given the permeable boundary between seagrasses and coral reefs, it is likely that the importance of allochthonous transfers of seagrass production to coral reefs has been greatly underestimated.

In fact, empirical evidence supports this contention. While many herbivorous fishes seek shelter on reefs at night, they commonly forage in nearby seagrass habitats throughout the day (Randall 1965, Ogden \& Zieman 1977, McAfee \& Morgan 1996). Moreover, the conspicuous presence of bare-sand 'halos' surrounding reefs created by herbivores shows that grazing on nearby seagrasses can be intense (e.g. Randall 1965, Ogden \& Zieman 1977, McAfee \& Morgan 1996). Although the intensity of grazing diminishes with increasing distance from the reef (MacIntyre et al. 1987), grazing by reefassociated herbivores and seagrass-resident herbivores is not limited to the areas immediately surrounding reefs (MacIntyre et al. 1987, Kirsch et al. 2002). Further, seagrass-resident herbivores are prey for a number of reefassociated piscivores, increasing the transfer of seagrass production throughout coral reef food webs (Clifton \& Robertson 1993, Kirsch et al. 2002).

There is now substantial anecdotal, descriptive, isotopic, and experimental evidence that herbivores consume significant quantities of seagrass biomass in many areas (see review by Valentine \& Duffy 2006). Even so, there is evidence that modern day grazing on seagrasses is anomalously low in subtropical and tropical ecosystems due to the recent overharvesting of green turtles and sirenians (summarized in Valentine \& Duffy 2006). While direct estimates of seagrass consumption by herbivores are few, a recent study has shown that substantial amounts of seagrass production are consumed by smaller herbivores in the vicinity of coral reefs (Kirsch et al. 2002).
It is also noteworthy that previous descriptions of seagrass herbivory were based primarily on observations from sites now known to have been intensely fished long before modern day investigations were conducted (Pandolfi et al. 2003). Among the many impacts of overfishing has been a worldwide depletion of piscivorous fish biomass to around $10 \%$ of historical levels (Myers \& Worm 2003). Additionally, herbivore biomass has been reduced on a number of reefs through indiscriminate harvesting by fishers using traps (e.g. Mumby et al. 2006). The consequences of these reductions in fish density for trophic exchanges between seagrass and coral reefs are unknown, but it seems clear that they have been reduced (Valentine \& Heck 2005). Conversely, it is also possible that recent estimates of grazing on seagrasses could reflect 'runaway' consumption by herbivores in locations where threats of attack by piscivores have been reduced to ecologically trivial levels (cf. Mumby et al. 2006). Evidence supporting this second alternative comes from a number of coral reefs where consumer reductions have been shown to have had dramatic cascading effects on lower trophic levels (McClanahan et al. 1995, McClanahan 1998). If the second alternative is true, then the few existing studies of grazing on seagrasses are likely to have greatly overestimated historical levels of consumption.

The Florida Keys are intensively fished year-round, with seasonal peaks during the winter tourist season and summer months (Bohnsack et al. 1994). During the 1970s, trap fishing was heavy throughout south Florida and concerns about wholesale reductions of fish stocks led to a 1980 ban of their use within 3 nautical miles offshore. Subsequently, trap fishing was also banned in federal waters in depths of less than $30 \mathrm{~m}$ (Bohnsack et al. 1989). Because indiscriminant trap fishing has been banned in the Florida Keys, reef fishing has mostly targeted large piscivores, including amberjacks Seriola dumerili, groupers (Serranidae), and to a lesser extent barracudas Sphyraena barracuda, and some omnivores, including hogfishes (Labridae), snappers (Lutjanidae), triggerfishes (Balistidae), and some grunt species (Haemulidae) (Bohnsack et al. 1994, Ault et al. 1998). Herbivores are not reported to be targeted on reefs anywhere within the Florida Keys (Ault et al. 1998).

In 1997, the US Congress designated an almost $10000 \mathrm{~km}^{2}$ area surrounding the Florida Keys as the Florida Keys National Marine Sanctuary (FKNMS) to protect its biodiversity and achieve sustainable use of reef resources. As a result, 23 replicate 'no-take' zones (designated as either 'sanctuary preservation areas' [SPAs] or, in 1 case, 'ecological reserve' [ER]) were established along the Florida Keys reef tract (see Fig. 1). The designation of these no-take zones limits the losses of most fishes to harvests at non-protected reefs. 
At the time of this study, reviews (Halpern \& Warner 2002, Halpern 2003, but see McClanahan \& Graham 2005 and Russ \& Alcala 2004) strongly indicated that the establishment of such no-take zones led rapidly (in 1 to $3 \mathrm{yr}$ ) to substantial increases in the density, body size, and biomass of most targeted fish species. A single study from the Florida Keys showed that reductions in fishing pressure led to an almost doubling of snapper density and a 4 -fold increase in the density of grunts only 2 yr after the establishment of Looe Key Reef as a no-take reef (Clark et al. 1989). In a second, as yet unpublished study (Fioravanti \& Valentine 2007), far greater abundances of snappers were found at more recently established no-take sites in the upper Florida Keys (Dry Rocks and Grecian Rocks SPAs) than at a nearby fished reef (Little Grecian Reef). Increased density of targeted fishes within such no-take zones has also been positively correlated with more abundant, and larger sized, targeted fishes in nearby fished areas (reflecting the spillover effect) (McClanahan \& Mangi 2000, Roberts et al. 2001, but see Shipp 2003). As such, persistent, often intense, fishing on unprotected reefs of the FKNMS represents a sustained predator-reduction treatment, and the no-take zones (where the harvest of marine organisms is prohibited) a predator-rich treatment. Thus, establishment of no-take zones in the Florida Keys has provided a unique opportunity to test the extent to which the abundance of piscivorous fishes controls the flow of energy from seagrasses to coral reef food webs via the grazing pathway.

Herein, we report the findings of a study that quantified grazing by both reef-associated and seagrass-resident herbivores in vegetated areas surrounding coral reefs in 2 widely separated regions of the Florida Keys. We also provide the first direct estimates of the quantity of seagrass production consumed by reef-associated parrotfishes and the extent to which the trophic exchange varies among locations and between regions. We also used the presence of areas protected from fishing to assess the extent to which the removal of piscivores from nearshore waters has altered the intensity of grazing across the seagrass-coral reef interface. Finally, we provide the first quantitative evaluation of the extent to which variation in herbivore guild composition varies with location and piscivore density.

\section{MATERIALS AND METHODS}

Experimental design. To quantify the amount of seagrass production reaching coral reef food webs via grazing and the extent to which the intensity of this trophic transfer is controlled by piscivores, we used a simple experimental design that measured multiple response variables at 2 distances (immediately adjacent, [5 m] to the reef, which we term 'near' and at 30 or $60 \mathrm{~m}$ into the seagrass [Thalassia testudinum] bed, which we term 'far') from replicated fished (predator-poor) and no-take (predatorrich) reefs. These reefs were located in 2 widely separated regions of the Florida Keys reef tract (Fig. 1). The present study was begun some 3 yr after the establishment of no-take reefs within the Florida Keys. As such, there should have been adequate time for densities of reef piscivores to have recovered prior to commencement of the study (Halpern \& Warner 2002, Halpern 2003).
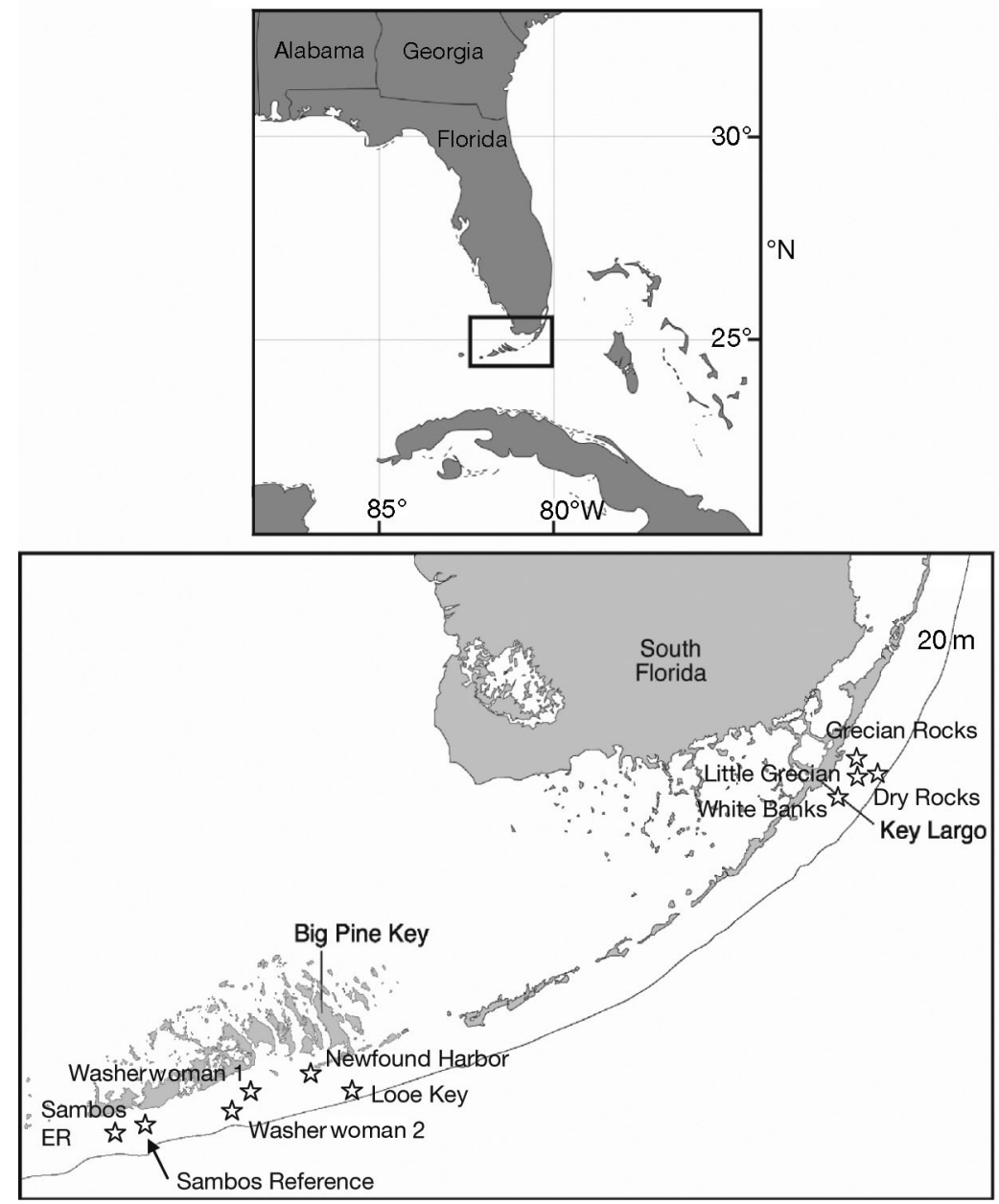

Fig. 1. Study locations in upper and lower Florida Keys (20 m isobar shown). ( $\downarrow$ ) Approximate locations of replicate study sites (see 'Materials and methods' for geographical coordinates). ER: Ecological reserve 
We predicted that there would be elevated densities of piscivorous fishes foraging in seagrasses near protected (no-take) coral reefs, and that this would lead to reductions in density and shifts in the relative abundances of grazers (from more larger reef-associated parrotfishes to fewer more secretive, smaller, seagrassresident parrotfishes) in the seagrass (Thalassia testudinum), and that grazing on seagrass would be lower near no-take reefs (Fig. 2). Conversely, we predicted that lower densities of piscivorous fishes in fished areas would allow reef-associated herbivores to forage freely throughout the seagrasses adjacent to fished reefs and that grazing intensity would be greater there (Fig. 2).

To test these predictions, a navigation line was anchored at a haphazardly located point at the base of each replicate coral reef (see next subsection for specific sites used in this study) and extended to distances of either 60 or $30 \mathrm{~m}$ into the adjacent seagrass bed in the upper and lower Florida Keys, respectively; transect length was shortened in the lower Keys based on results from the first 2 yr of study in the upper Keys. The transect was established, with the aid of observers on the boat, such that it lay perpendicular to the perimeter of the reef. Data were collected in areas directly adjacent to the reef (hereafter referred to as the near site) and at the end of the transect (hereafter referred to as the far site).

Data were collected in the upper Florida Keys in July and September 2000 and May and September 2001, and in the lower Florida Keys in May, July, and August 2002 and May and August 2003.

Study sites. As far as possible, structurally similar fished and no-take reefs, with extensive seagrass habitats adjacent to the landward sides of the reef were selected for study. In the upper Keys, experiments were conducted in 2 no-take zones, Grecian Rocks and Dry Rocks SPAs, and at 2 fished sites, White Banks and Little Grecian Reefs (Fig. 1). In the lower Keys, experiments were conducted in the back reef environments of 3 no-take sites, Newfound Harbor, Looe Key SPAs and Western Sambos Ecological Reserve (ER) and 3 fished sites, 1 near the ER and 2 along the Washerwoman Reef Tract (Fig. 1). The geographical coordinates were Grecian Rocks, $25^{\circ} 06.91^{\prime} \mathrm{N}, \quad 080^{\circ} 18.20^{\prime} \mathrm{W}$; Dry Rocks, $25^{\circ} 07.59^{\prime} \mathrm{N}, 080^{\circ} 17.91^{\prime} \mathrm{W}$; White Banks, $25^{\circ} 02.442^{\prime} \mathrm{N}, \quad 080^{\circ} 22.276^{\prime} \mathrm{W}$;

Decreases and smaller

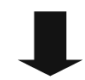

Reduced seagrass grazing
Little Grecian Reefs, $25^{\circ} 06.91^{\prime} \mathrm{N}, 080^{\circ} 18.20^{\prime} \mathrm{W}$; Newfound Harbor, $24^{\circ} 36.925^{\prime} \mathrm{N}, 081^{\circ} 23.642^{\prime} \mathrm{W}$; Looe Key, $24^{\circ} 32.830^{\prime} \mathrm{N}, 081^{\circ} 23.642^{\prime} \mathrm{W}$; ER, $24^{\circ} 28.879^{\prime} \mathrm{N}, 081^{\circ}$ $43.172^{\prime} \mathrm{W}_{\text {; }}$ patch site near ER, $24^{\circ} 31.698^{\prime} \mathrm{N}, 081^{\circ}$ $39.205^{\prime} \mathrm{W}^{\prime} 2$ sites along West Washerwoman Reef tract, $24^{\circ} 32.890^{\prime} \mathrm{N}, 081^{\circ} 35.414^{\prime} \mathrm{W}$ and $24^{\circ} 33.316^{\prime} \mathrm{N}, 081^{\circ}$ 33.835' W.

Response variables. Fish density and composition: Two commonly used visual census techniques were used to document treatment effects on piscivore and herbivore density and composition: point counts and belt transects. Visual census methods have been used extensively to describe the community structure and estimate the density of reef fishes (Bohnsack \& Bannerot 1986, Edgar \& Barrett 1999). Although observer error and behavioral interactions between divers and fishes can bias the results of visual censuses (e.g. Sale \& Douglas 1981, Kulbicki 1998), direct counts are considered to be reliable for most readily observable species.
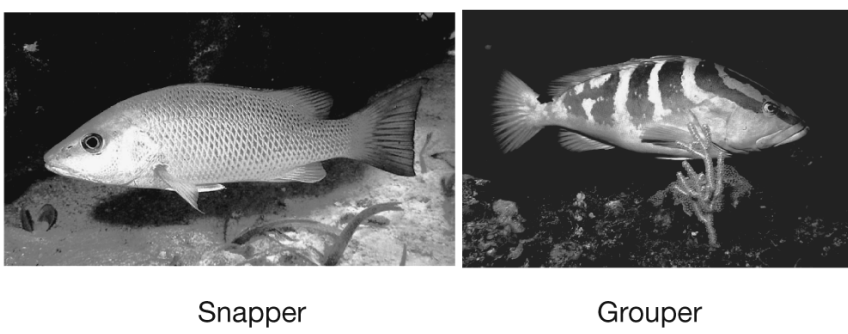
in herbivorous predatory fishes

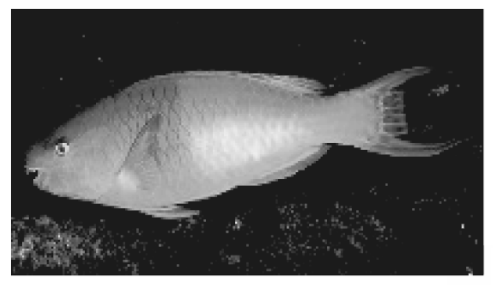

Parrotfish

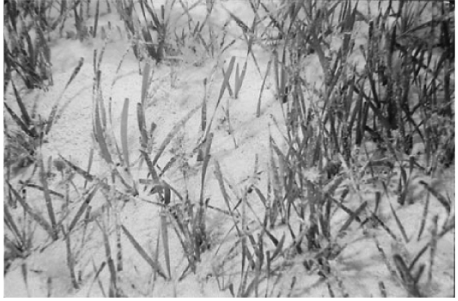

Thalassia
Fig. 2. Predicted impacts at no-take sites of elevated piscivore reef fish density on seagrass (Thalassia testudinum) herbivores and grazing intensity in the sanctuary preservation areas. Diagram: scanned leaf image showing bite marks. Snapper, grouper and parrotfish images courtesy of R. Froese and D. Pauly (editors, FishBase 2006, www.fishbase.org, version 02/2006) 
SCUBA-equipped observers made counts of piscivore- and reef-associated herbivore composition and density, at both the near and far sites, using a slightly modified version of the stationary point method of Bohnsack \& Bannerot (1986). The only modification was that 2 intersecting $10 \mathrm{~m}$ long lines were used to mark the center point of an imaginary cylinder extending upward from that point to the overlying water surface. During each sampling event, the diver knelt at the intersection of the 2 lines and identified (to the species level in most cases) and enumerated all fishes entering the area of the circle over a 15 min period. Counts were limited to days when visibility exceeded $20 \mathrm{~m}$, and the divers conducting surveys at the near and far sites were the same throughout each visit. Because piscivore and herbivore composition and density varies greatly from day to day (Sale \& Douglas 1981), visual surveys were repeated on 3 separate days at each distance and site during each of the previously reported survey times.

Belt transect surveys were conducted a few minutes after the point counts to provide a comparative estimate of the densities and compositions of herbivorous fishes. To do this, $20 \times 1 \mathrm{~m}$ transect lines were established parallel to the reef edge, at both near and far distances from the reef. Separate SCUBA-equipped observers swam the transect lines for a $5 \mathrm{~min}$ period with a $1 \mathrm{~m}$ long T-bar. All herbivores observed within the $20 \mathrm{~m}^{2}$ area (as determined by the T-bar) were counted and identified. These counts were also repeated on 3 separate days at the near and far locations for the months, years, and sites described above (subsection 'Experimental design'). Piscivores were not recorded in these surveys as we anticipated that belt transect surveys would not accurately depict the densities of these highly vagile consumers.

Grazing intensity: We quantified seagrass grazing intensity following methods described in Kirsch et al. (2002). To estimate the risk that reef-associated herbivores were willing to take in foraging in seagrass habitats adjacent to the reefs, tethered seagrass shoots (see next paragraph) were placed at each site at distances of $5,10,20,40$, and $60 \mathrm{~m}$ from each reef in the upper Keys, and at 5, 10, 20, $30 \mathrm{~m}$ from each reef in the lower Keys. Transect length was shortened in the lower Keys as we found no evidence of statistically significant differences in leaf loss at distances of 20, 40 and $60 \mathrm{~m}$ from reefs surveyed in the upper Keys. Tethers placed at distances of 5 and $10 \mathrm{~m}$ from the reef were grouped together to estimate grazing near the reef and tethers placed at distances of 20,30,40, or $60 \mathrm{~m}$ were grouped together to estimate grazing away from the reef (cf. MacIntyre et al. 1987).

Turtlegrass shoots Thalassia testudinum were collected from Rodriquez Key $\left(25^{\circ} 03.200^{\prime} \mathrm{N}, 080^{\circ} 27.1^{\prime} \mathrm{W}\right)$ in the upper, and Little Palm Island $\left(24^{\circ} 37.11^{\prime} \mathrm{N}\right.$, $\left.081^{\circ} 24.42^{\prime} \mathrm{W}\right)$, in the lower Keys. Leaves were severed from the collected shoots at the top of the sheath and examined for bite marks. If bite marks were present, the shoots were severed below the bite mark to provide uniformity in leaf appearance. Leaves were digitally scanned (Hewlett Packard ${ }^{\circledR}$, flat-bed scanner), then rebundled into shoots and attached to a $0.25 \mathrm{~m}$ long sisal line with a clothespin. Each sisal line (or tether) contained 3 evenly spaced shoots. Three lines of tethers, containing a total of 9 shoots, were placed at the specified distances from the reef at each study site. Tethers were anchored using wire stakes that were pushed into the sediment such that they simulated the appearance of natural shoots within a seagrass bed. Tethers were retrieved after $24 \mathrm{~h}$ and replaced with a new set of shoots. The remaining leaves on the retrieved tethers were rescanned in the laboratory to estimate losses of leaf tissue due to grazing. This process was replicated for $3 \mathrm{~d}$ during each visit to the study sites.

Grazing by large reef-associated herbivores-bite size: Because our point counts and belt transects were limited to a very small proportion of each survey day, we evaluated the longer-term impacts of piscivore density on grazing by both larger, reef-associated, parrotfishes, and smaller, seagrass-resident parrotfishes by bite size. We measured bite size on randomly selected shoots from tethers and on shoots from production quadrats (see next subsection), both near and far from each of the reefs during each survey period. Bite width, an indicator of herbivory by either a reefassociated or a seagrass-resident herbivore, was determined from calibrated, scanned, leaf images that were imported into the commercially available Sigma Scan $^{\mathrm{TM}}$ digitizing software (cf. Kirsch et al. 2002). Once scanned, bite widths were categorized as being due to feeding by either a larger reef-associated herbivore or a smaller seagrass-resident herbivore. To provide a benchmark for this categorization, undamaged turtlegrass leaves were placed in $37.8 \mathrm{l}$ aquaria with a known, abundant, seagrass-resident herbivore (adult bucktooth parrotfish Sparisoma radians) (Randall 1967). The turtlegrass leaves were removed after $2 \mathrm{~h}$ and the widths of the bites were determined as described above. Bite sizes for the bucktooth parrotfish ranged from 0.32 to $0.59 \mathrm{~cm}(\mathrm{n}=31)$. With the benchmark established, all bites with widths $>0.59 \mathrm{~cm}$ were considered to have been made by a larger reef-associated parrotfish, while smaller bite widths were assigned to the seagrass-resident category.

Seagrass density, production and aboveground biomass: To quantify the amount of seagrass production consumed by herbivores, estimates of net aboveground primary production (NAPP) and aboveground 
seagrass biomass were made from 3 replicate $0.01 \mathrm{~m}^{2}$ quadrats placed at distances of $5 \mathrm{~m}$ and either $30 \mathrm{~m}$ (lower Keys) or $60 \mathrm{~m}$ (upper Keys) from the reef at each site and during each sampling period.

We estimated NAPP using a modified punch-hole technique (Kirkman \& Reid 1979). Initially, turtlegrass shoots within the haphazardly placed quadrats were marked at the top of the leaf sheath; after 7 to $12 \mathrm{~d}$, all marked shoots were removed, placed in prelabeled plastic bags, and returned to the laboratory for processing. In the laboratory, both the area and the biomass of the new and old growth, along with shoot density, were measured. The new growth was defined as the area and weight of leaf tissue between the initial punch-hole scar and the top of the leaf sheath, plus any new unmarked leaves. The new growth and remaining old growth were first scanned to determine the new leaf area produced and the total leaf area, and then all the material was dried at $60^{\circ} \mathrm{C}$ to a constant mass. This mass was standardized to estimate NAPP as g dry mass $\mathrm{m}^{-2} \mathrm{~d}^{-1}$. Total aboveground seagrass biomass was also determined for these same quadrats.

Seagrass consumption by reef herbivores: To estimate cross-habitat energy exchanges at our study sites and the extent to which trophic transfer varied both within and between regions, we first estimated reef perimeter from 'Geographic Information System' GISbased maps of each reef using ARCVIEW software. This estimate was then multiplied by 10 (the farthest distance in meters at which large parrotfish grazing was detected), to provide a conservative estimate of the area over which reef-associated herbivores were feeding. Next, we estimated the quantity of seagrass production transferred to the reef via grazing by converting site-specific daily rates of areal leaf loss on our tethers (calculated on a per shoot basis) to biomass on a per shoot basis $(y=0.2228+190.08 x$, where $y=$ biomass lost per shoot and $x=$ leaf loss in $\mathrm{cm}^{2} ; F_{156}=$ 931.145, $\mathrm{p}<0.0001, \mathrm{r}^{2}=0.86$ ). We then multiplied this value by the estimated total number of shoots along the perimeter of the reef, which was based on mean shoot density determined from the quadrats. From the NAPP estimates, daily estimates of the area of new leaf growth $\left(\mathrm{cm}^{2}\right)$ shoot ${ }^{-1}$ were regressed on the estimate of leaf mass $(\mathrm{g})$. These daily estimates of production were then converted to an annual estimate of cross-habitat energy exchange by multiplying by $365 \mathrm{~d}$.

Statistical analyses. Replicate definition: Main treatment effects included region (sites in the upper and lower Florida Keys), fishing pressure (fished and notake sites) and distance from the reef (near and far). To evaluate our predictions, we repeated data collection 2 to 3 times in each of the 2 yr study periods (see subsection 'Experimental design') at all sites. Estimates of different variables were generated from the mean of the 3 repeated measures of piscivore density, herbivore density, proportional losses of tethered leaves, and the proportion of herbivore bites on tethered leaves whose diameter was $>0.59 \mathrm{~cm}$.

Treatment effects on piscivore and herbivore density and guild composition: Piscivores included in comparisons were limited to those predators known to eat seagrass herbivores (as documented by Randall 1967 and McAfee \& Morgan 1996). Those encountered during our point count surveys were barracudas Sphyraena barracuda, rock hinds Epinephelus adscensionis, black groupers Mycteroperca bonaci, mutton snappers Lutjanus analis, yellow jacks Caranx bartholomaei and bar jacks C. ruber (Table 1). Known seagrass herbivores were limited to species of parrotfishes in the genera Sparisoma and Scarus (Table 1).

Evaluations of treatment effects and their interactions on piscivore and herbivore density were made using 3-way analyses of variance (ANOVAs), testing for differences between regions, between distances from the reef, and between fished and no-take reefs. Data from point and belt transect surveys were either square root- or $\log _{10}$-transformed data, respectively. When no significant interactions were detected, they were removed from the model and the analyses were repeated. If significant interactions were detected, comparisons of main effects impacts on the dependent variable of interest are simply discussed.

In some cases, violations of homogeneity of variance were the direct result of the high variance to mean ratios for episodically encountered schooling fishes. Since there is no nonparametric analog of 3-way

Table 1. Piscivores observed in point and belt counts and known to be predators of parrotfish (Randall 1965, 1967, McAfee \& Morgan 1996), and seagrass herbivores (parrotfishes) observed in point and belt counts

\begin{tabular}{|ll}
\hline Common name & Scientific name \\
\hline Piscivores & \\
Barracuda & Sphyraena barracuda \\
Rock hind & Epinephelus adscensionis \\
Black grouper & Mycteroperca bonaci \\
Mutton snapper & Lutjanus analis \\
Yellow jack & Caranx bartholomaei \\
Bar jack & Caranx ruber \\
& \\
Seagrass herbivores & \\
Redband & Sparisoma aurofrenatum \\
Stoplight & Sparisoma viride \\
Yellowtail & Sparisoma rubripinne \\
Rainbow & Scarus guacamaia \\
Bucktooth & Sparisoma radians \\
Midnight & Scarus coelestinus \\
Redtail & Sparisoma chrysopterum \\
Unidentified small & \\
parrotfishes & \\
\hline
\end{tabular}


ANOVA, the results of 3-way ANOVA and the violation of the assumption are reported. In cases where the null hypothesis was not rejected, the analyses are simply presented since ANOVA is robust to violations of homogeneity of variance with respect to Type II errors (failing to reject a false null hypothesis; Underwood 1981). In cases where the main effects or their interactions were significant, treatment impacts were compared by plotting the data. Comparisons of main effect impacts on the composition of the piscivore and herbivore guilds were made using the nonparametric analysis of similarity technique (ANOSIM; 4th root transformed, Bray-Curtis similarity technique) (Clarke 1993).

Results in all comparisons were considered to be significant when $\mathrm{p}<0.05$. All parametric analyses were conducted using SPSS ${ }^{\mathrm{TM}}$ Version 11.0 statistical software package. ANOSIM and SIMPER comparisons were made using the multivariate nonparametric software package Primer-ETM.

Treatment effects on grazing intensity and bite size: Each tether was considered to be a replicate and the average amount of the tissue lost, on a per shoot basis, on the 3 tethers provided a daily estimate of grazing at each site and distance during a survey. Daily areal losses of tissue were calculated by multiplying this loss by the average density of shoots estimated from the NAPP quadrats (cf. Kirsch et al. 2002). The areal losses were then divided by the areal estimate of leaf production to provide an estimate of grazing intensity. The results of this conversion provided a standardized estimate of grazing intensity that can easily be compared with previously published estimates of the proportion of seagrass production consumed by herbivores (Valentine \& Duffy 2006). Main treatment effects impacts (region, fishing pressure, and distance from the reef) on grazing intensity were tested using a 3-way ANOVA on arcsine square root transformed estimates of the proportion of NAPP consumed by grazers. Similarly, the impacts of the main effects on the daily rates of grazing by larger reef-associated grazers on seagrasses adjacent to the reef were tested using a 3-way ANOVA of arcsine square root transformations of the proportions of tethered shoots with bite widths $>0.59 \mathrm{~cm}$.

Treatment effects on NAPP and aboveground biomass: Comparisons of NAPP and aboveground seagrass biomass were analyzed using 3-way ANOVA, with interactions, region (upper vs. lower Keys), fishing pressure (fished vs. no-take), and distance (near vs. far) as factors. If the data did not satisfy the assumption of homogeneity of variance for ANOVA, main effects comparisons for NAPP and aboveground biomass were made following log transformation of the data.
Synergistic relationships: We used both Kendall's tau-b and Pearson's product moment correlation analyses on untransformed data to evaluate the predictions regarding the impacts of piscivore removal on seagrass herbivory (herbivore density, grazing, seagrass growth, biomass, and density). When significant $(p<0.05)$ positive correlations between variables of interest were detected, the findings are reported. When negative relationships were detected, the relationship between the transformed (either square rootor $\log _{10}$-transformed) variables was evaluated further using simple linear regression.

\section{RESULTS}

\section{Treatment effects on piscivore density}

Three piscivore species (bar jacks Caranx ruber, yellow jacks C. bartholomaei, and great barracuda Sphyraena barracuda) accounted for $\sim 98 \%$ of all individuals recorded during point count surveys. Three others (rock hinds Epinephelus adscensionis, black groupers Mycteroperca bonaci, and mutton snappers Lutjanus analis) were encountered only at no-take reefs and their total abundance was $<10$ individuals. Therefore, evaluations of treatment effects were limited to the 3 most abundant piscivores.

Bar jacks were by far the most abundant of the piscivores, and we encountered them mostly in dense schools (variance to mean ratios ranging from $74: 1$ to 15:1 in the upper and lower Florida Keys, respectively). Bar jacks were far more abundant at near than at far sites (log-transformed counts: $F_{1,68}=7.64 ; \mathrm{p}<0.007$; Fig. 3a). There were no other significant treatments effects on bar jack density, nor were there significant interactions between treatments.

Great barracuda were encountered in smaller schools than bar jacks (variance to mean ratios of 5:1 to 9:1) (Fig. 3b). This resulted in the point count data violating the ANOVA homogeneity of variance assumption, regardless of transformation. Logtransformed counts of great barracuda were higher in the lower than upper Keys $\left(F_{1,68}=4.62\right.$, p $<0.035_{\text {; }}$ Fig. $3 b)$, and more so near than far from the reefs $\left(F_{1,68}=6.49 ; \mathrm{p}<0.013\right.$; Fig. $\left.3 \mathrm{~b}\right)$. No other significant effects on great barracuda density were detected $(\mathrm{p}>0.05)$.

Yellow jacks were encountered infrequently $(<5 \%$ of all counts), and in much lower densities than the 2 other species of piscivores. While yellow jacks were more abundant far from reefs in the upper Keys, the opposite pattern was true in the lower Keys (Fig. 3c). 

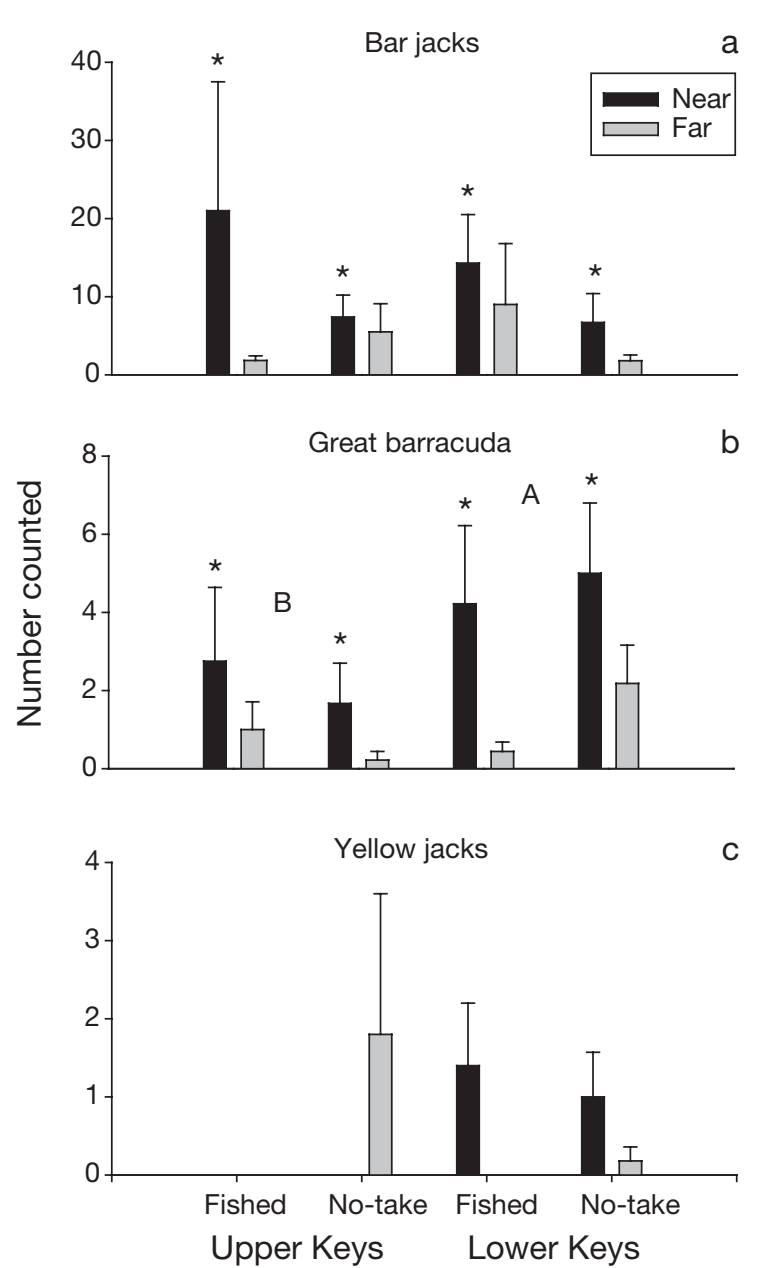

Fig. 3. Distributional pattern of dominant piscivores during point counts in upper and lower Florida Keys; 'Near' $=5 \mathrm{~m}$ and 'Far' $=60 \mathrm{~m}$ (upper Keys) or $30 \mathrm{~m}$ (lower Keys) into seagrass bed. Uppercase letters denote statistically significant differences between regions, asterisks statistically significant differences between distances from reef. Values are treatment means $+1 \mathrm{SE}$

\section{Treatment effects on herbivore composition and density}

Parrotfishes recorded during our surveys fell into 2 categories: schools of larger reef-associated (yellowfin, redtail, redfin, princess, stoplight, midnight and rainbow), and smaller seagrass-resident parrotfishes (bucktooth and unidentified juvenile parrotfishes). While $\log _{10}$-transformed counts of large parrotfishes failed to satisfy the assumption of homogeneity of variance for ANOVA, significant differences between distances existed $\left(F_{1,61}=24.89 ; \mathrm{p}<0.0001\right)$. Overall there were more large parrotfishes in the no-take zones, but this was only apparent in the lower Keys (interaction between region and fishing pressure: $F_{1,61}=15.91 ; \mathrm{p}<$ 0.001) (Fig. 4a).
Fishing pressure had a significant effect on square root transformed counts of seagrass-resident parrotfishes $\left(F_{1,62}=12.97 ; 62 ; \mathrm{p}<0.001 ;\right.$ Fig. $\left.4 \mathrm{~b}\right)$ : These fishes were about twice as abundant at no-take reefs than at fished reefs. No other significant main effects or interactions were detected between regions or between distances from the reef.

Herbivore composition varied significantly between regions (2-way crossed ANOSIM: global $\mathrm{R}=0.097$; $\mathrm{p}=$ 0.023 ) and with levels of fishing pressure (global $\mathrm{R}=$ $0.154 ; \mathrm{p}=0.04)$. More reef-associated species of parrotfishes were recorded in point counts in the lower Keys. SIMPER analysis detected modest differences in redtail and stoplight parrotfish abundances between regions. Additionally, counts of rainbow and yellowtail parrotfishes were limited to sites in the lower Keys.

A second 2-way crossed ANOSIM showed that small parrotfish (mostly bucktooth) species composition also varied significantly between regions (global $\mathrm{R}=0.132$; $p=0.001$ ) and with levels of fishing pressure (global

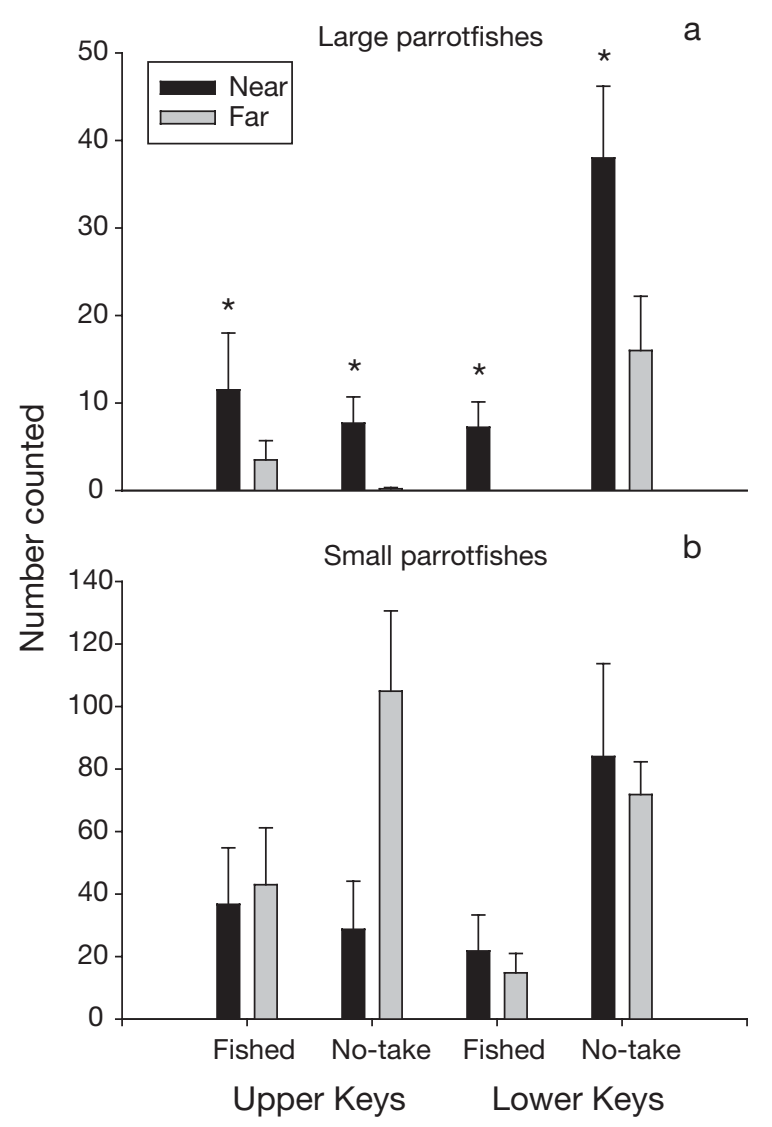

Fig. 4. Distributional patterns of (a) larger reef-associated and (b) smaller seagrass-resident parrotfishes during point counts at study sites in upper and lower Florida Keys. All differences between fished and no-take reefs were significantly different at $\mathrm{p}<0.05 ;\left({ }^{*}\right)$ Statistically significant differences between distances from reef; for definition of 'Near', 'Far' see Fig. 3. Values are treatment means $+1 \mathrm{SE}$ 
$\mathrm{R}=0.105 ; \mathrm{p}=0.005)$. In addition, the small parrotfish species composition differed significantly with distance from the reef (global $\mathrm{R}=0.08 ; \mathrm{p}=0.015$ ).

Stoplight, rainbow, and yellowtail parrotfishes accounted for $71.4,19.4$ and $9.2 \%$ of grazers recorded, respectively, in the belt transect surveys. Redtail parrotfish were not recorded on the belt transects. Large parrotfish were encountered in schools. Variance to mean ratios ranged from 14.5:1 and from 21:1 for yellowtail and stoplight parrotfishes, respectively. As a result, the assumption of homogeneity of variance for ANOVA was violated.

Log-transformed counts of reef-associated parrotfishes on the belt transects diminished significantly with increasing distance from the reef $\left(F_{1,77}=6.45 ; \mathrm{p}<\right.$ 0.02), being about twice as abundant at near than at far sites (Fig. 5a). Large reef-associated parrotfishes were also significantly more abundant at no-take than at fished sites $\left(F_{1,77}=5.28 ; \mathrm{p}<0.024\right)$, regardless of region (Fig. 5a). Stoplight and rainbow parrotfishes were most abundant near reefs. The results of ANOSIM differed somewhat from those of the point surveys in that the

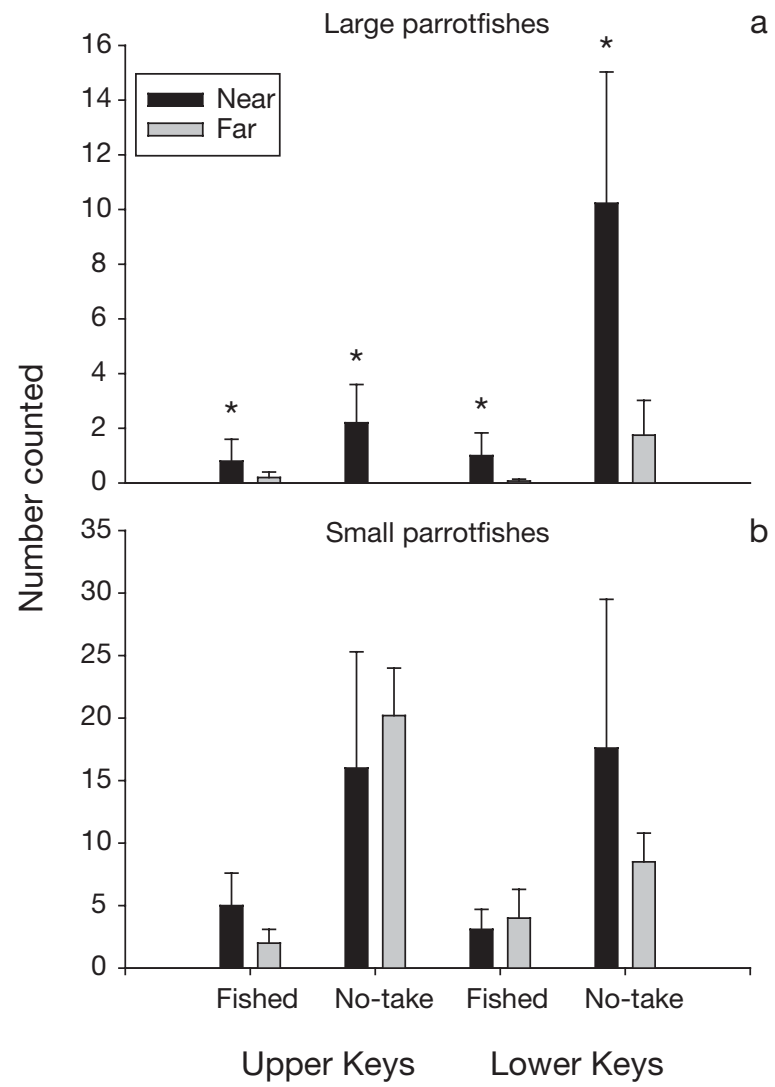

Fig. 5. Distributional patterns of (a) larger reef-associated and (b) smaller seagrass-resident parrotfishes during belt counts at study sites in upper and lower Florida Keys. All differences between fished and no-take reefs were significantly different at $\mathrm{p}<0.05$. Symbols and definitions as in Figs. $3 \& 4$. Values are treatment means $+1 \mathrm{SE}$ composition of large parrotfishes did not vary with fishing pressure (global $\mathrm{R}=0.013 ; \mathrm{p}=0.292$ ) or region (global $\mathrm{R}=0.02 ; \mathrm{p}=0.222$ ). While differences in herbivore composition between distances were apparent, they were not significant (global $R=0.02$; $p=0.056$ ).

Log-transformed counts of seagrass-resident parrotfishes varied significantly with fishing pressure $\left(F_{1,77}=\right.$ 14.95; $\mathrm{p}<0.0001)$. Densities of these smaller parrotfishes were on average 5 times greater at no-take sites, regardless of distance from the reef, than at the fished sites (2.8 parrotfish vs. 0.42 per $20 \mathrm{~m}^{2}$ ), and markedly so in the upper Keys (Fig. 5b). No significant differences were detected between regions or distances from the reef.

Small parrotfish composition varied significantly with region (global $\mathrm{R}=0.115, \mathrm{p}=0.017$ ) and fishing pressure (global $\mathrm{R}=0.168, \mathrm{p}=0.001$ ). As a result, additional crossed (treatment $\times$ distance) ANOSIMs were conducted on surveys from the upper and lower Keys. Compositions of these parrotfishes varied greatly with fishing pressure in both regions (lower Keys: global $\mathrm{R}=$ 0.245 ; $\mathrm{p}=0.001$, upper Keys: global $\mathrm{R}=0.227, \mathrm{p}=$ $0.024)$. These differences do not seem to be ecologically relevant, as they are best explained by the higher proportion of unidentifiable small parrotfishes observed at the no-take sites. At the fished sites in the lower Keys, there were 292 bucktooths and only 17 unidentified parrotfishes, whereas in the no-take areas we observed 979 bucktooths and 230 unidentified individuals.

Comparisons of herbivores recorded in the 2 survey types produced complementary results. There was a high degree of overlap in the species composition of parrotfishes recorded by the 2 approaches. All but redtail and midnight parrotfishes were recorded in both surveys. Of these, only redtail parrotfish were recorded in abundance, so it seems likely that we adequately characterized the herbivore guild at the study sites. Significant positive correlations between counts made using point and belt transect survey methods were found for stoplight (tau-b $=0.498, \mathrm{p}<0.001$ ), yellowtail (tau-b $=0.463, \mathrm{p}<0.007$ ), and rainbow (tau-b $=0.396, \mathrm{p}<0.018$ ) parrotfishes, indicating that our characterizations of treatment effects on the grazer density and composition were consistent.

\section{Treatment effects on grazing intensity}

Grazing intensity varied significantly with region $\left(F_{1,68}=21.13 ; \mathrm{p}<0.0001 ;\right.$ Fig. $\left.6 \mathrm{a}\right)$, and distance from the reefs $\left(F_{1,77}=4.59 ; \mathrm{p}<0.036\right)$ and was higher in the upper than in the lower Keys, and higher near than far from reefs. Grazing was over $200 \%$ > seagrass production near reefs in the upper Keys (Fig. 6a). In stark contrast, grazing never exceeded $48 \%$ of seagrass production in the lower Keys. Grazing was also substantial at 

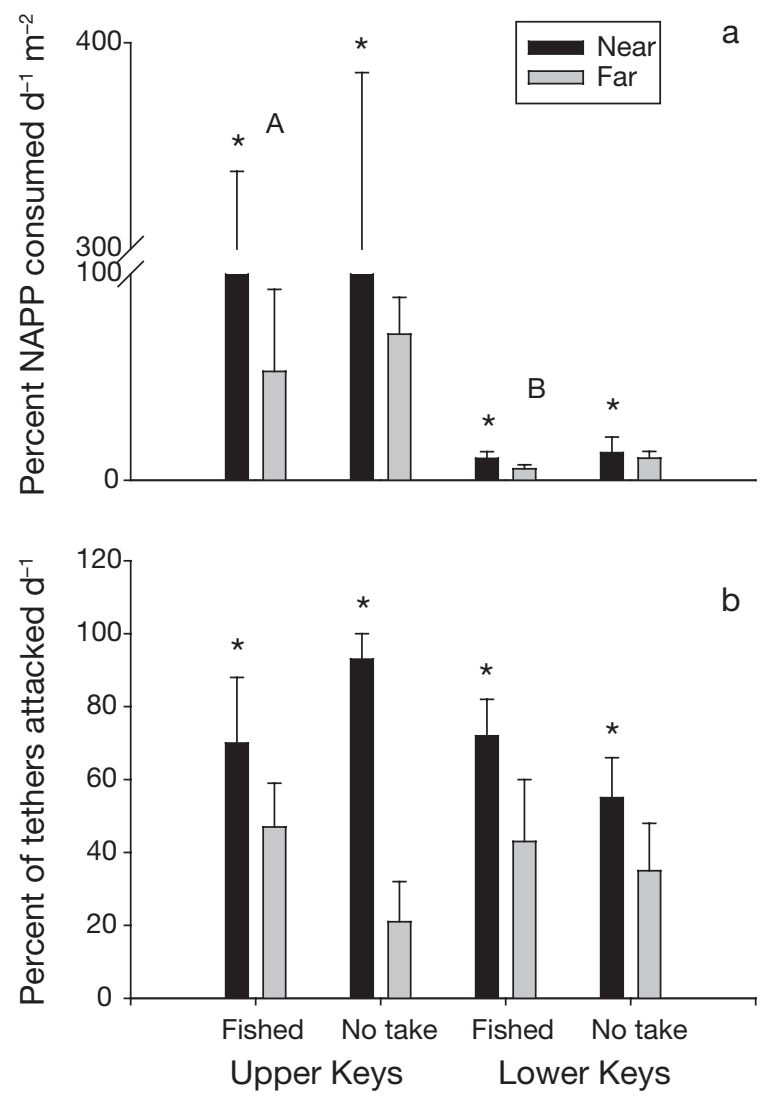

Fig. 6. Fishing effects on proportion of (a) net aboveground primary production (NAPP) consumed and (b) seagrass tethers attacked at varying distances from fished and unfished reefs in upper and lower Florida Keys. Near: 5 to 10 m; Far: 20 and $30 \mathrm{~m}$ (lower Keys) or 20, 40, 60 m (Upper Keys) Symbols as in Fig. 3. Values are treatment means $+1 \mathrm{SE}$

far sites (ranging between one half and two-thirds of the measured seagrass production) in the upper Keys.

\section{Treatment effects on parrotfish bite size}

The proportions of tethered shoots and shoots harvested from quadrats that were bitten by larger reefassociated herbivores were similarly high near reefs ( $>60$ and $>80 \%$ of shoots on tethers or harvested from quadrats, respectively) (Fig. 6b). The number of bites by large herbivores varied significantly only with distance from the reefs $\left(F_{1,62}=24.53 ; \mathrm{p}<0.0001\right)$.

Regional differences in grazing were due to differences in feeding by reef-associated parrotfishes. The correlation between the arcsine-transformed proportions of leaf losses on tethers and proportions of tethered shoots bitten by large parrotfishes was significant (tau-b $=0.431 ; \mathrm{p}<0.001$ ), but the correlation between the arcsine-transformed proportions of tissue loss on tethers and numbers of bites on shoots harvested from production quadrats was not (tau-b $=0.05, \mathrm{p}>0.71$ ).
Nor was the correlation between proportions of bites by large parrotfishes on tethers and on shoots from the production quadrats (tau-b $=-0.118, \mathrm{p}>0.43$ ).

Using GIS-based estimates of reef perimeter, bite widths on tethers, and daily rates of leaf loss on tethered shoots, we estimated that, on average, $9.2 \mathrm{t}$ of seagrass production (range 0 to 18.28) are eaten by larger reef-resident parrotfishes each year at the reefs examined in the upper Keys. For the lower Keys, the estimates were much lower, averaging around $0.75 \mathrm{t}$ $\mathrm{yr}^{-1}$ (range: 0 to 2.422 ) at the reefs examined in this study.

\section{Treatment effects on NAPP and aboveground biomass}

Log-transformed estimates of daily rates of production showed that NAPP was significantly greater in the lower than in the upper Keys $\left(F_{1,74}=11.97 ; \mathrm{p}<0.001\right.$; Fig. 7a), but did not vary significantly with distance from reefs or level of fishing pressure. Log-transformed estimates of aboveground biomass were signif-
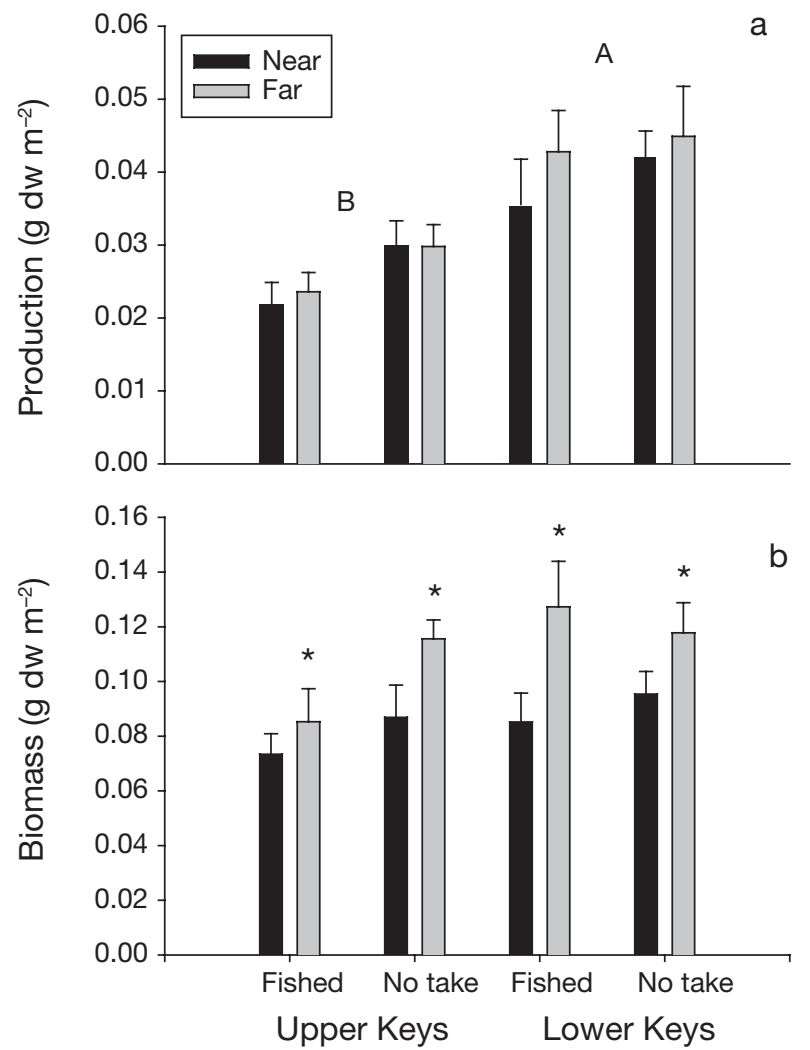

Fig. 7. Thalassia testudinum. Net aboveground (a) primary production and (b) biomass of seagrass near and far from reefs. For definition of 'near' and 'far' see Fig. 6. Symbols and definitions as in Fig. 3; dw = dry weight. Values are treatment means $+1 \mathrm{SE}$ 
icantly lower near than far from reefs $\left(F_{1,74}=10.59 ; \mathrm{p}<\right.$ 0.002 ; Fig. 7b). No other significant main effects or interactions were detected.

\section{Piscivore impact on herbivore density and seagrass}

Because significant treatment effects were primarily limited to areas near reefs, and because of the absence of the anticipated treatment effect on piscivore density, we refocused our attention on data collected from sites near reefs.

The anticipated significant negative correlations between log-transformed densities of barracuda and parrotfishes were not detected. Nor did we find the anticipated significant positive correlations between log-transformed densities of any species of parrotfishes and proportional losses of leaf tissue on the tethers. We did, however, find a significant positive correlation between the arcsine-transformed proportions of tethered shoots with bites made by larger parrotfishes and the arcise-transformed proportions of leaf tissue lost from the tethers $(r=0.489, p<0.004, n=33)$. A negative correlation between the arcise-transformed losses of leaf tissue on the tethers and log-transformed NAPP ( $\mathrm{r}=-0.321, \mathrm{p}<0.078, \mathrm{n}=33$ ) was not significant, nor was a negative correlation between great barracuda density and arcise-transformed losses of leaf tissue on tethered shoots $(\mathrm{r}=-0.321, \mathrm{p}<0.068, \mathrm{n}=33)$. Additional regressions suggested that linear relationships between visual estimates of piscivore density, the proportion of shoots attacked by larger reef-associated parrotfishes, leaf loss on tethers, and seagrass growth were not strong $(p>0.05)$.

\section{DISCUSSION}

Despite emerging evidence showing the importance of exogenous inputs of nutrients to coral reef food webs (e.g. Leichter et al. 2003), most investigators adhere to the view that reef food webs are closed entities characterized by tight recycling processes (Hatcher 1997). Qualitatively, we know that trophic links exist between reefs and surrounding habitats, yet we know of no direct estimates of the intensity of this exchange (reviewed in Bascompte et al. 2005, Valentine \& Duffy 2006). Before the present study there were no known direct estimates of how much seagrass production reaches reef food webs via grazing in seagrass meadows. Using GIS-based estimates of reef perimeter at our study sites, measurements of bite widths on tethers and daily rates of tethered leaf loss, we estimated, on average, that $9.2 \mathrm{t}$ of seagrass production (ranging from 0 to $18.28 \mathrm{t}$ of seagrass production among the 4 sites) are eaten by larger reef-resident parrot fishes each year at the study sites in the upper Keys. The magnitude of this transfer can apparently vary greatly among regions as these estimates are much lower, averaging around $0.75 \mathrm{t} \mathrm{yr}^{-1}$ (range 0 to 2.422) for the lower Keys. Given the high levels of grazing by smaller herbivores, which are known prey for a number of reef-associated piscivores in the upper Keys, it is likely that our estimates of energy transfer from seagrasses to reefs via grazing are low in the upper Keys.

Marine herbivores have never been observed to graze uniformly across any single habitat or landscape (e.g. Ogden et al. 1973, Hay 1981) and this was certainly not the case in our study. At the landscape scale, seagrass grazing was 5 times greater in the upper than in the lower Keys. At the scale of the reefs, attacks by large herbivores on tethered shoots and on shoots harvested from quadrats were similarly high near reefs ( $>60$ and $>80 \%$ of tethered shoots and shoots harvested from quadrats, respectively). Grazing was also substantially greater away from reefs in the upper Keys (ranging between one half and two-thirds of the measured seagrass production).

If modern day estimates of grazing on seagrasses are anomalously high due to the truncation of reef food webs by fishers, we should have found dramatic differences in herbivory on seagrasses between sites protected from fishing and those that are not. This was not the case: rates of herbivory on seagrasses were not much lower at sites protected from fishing than at sites where fishing continues. While the composition of parrotfishes varied significantly with distance from reefs, there was no evidence that differences in density or composition of reef-associated herbivores between regions contributed to regional differences in grazing. The significant regional differences in herbivore composition detected in ANOSIM analyses were simply the result of shifts in the relative abundances of the 2 numerically dominant species recorded in the point counts rather than large differences in species composition. Unexpectedly, large reef-associated parrotfishes were significantly more abundant at no-take than at fished sites, regardless of region. This finding is similar to that of Mumby et al. (2006), who found elevated densities of large parrotfishes in a predator-rich marine reserve in Bahamas. The mechanism proposed to explain this abundance of grazers was protection from collection by trap fisherman. This explanation does not, however, explain the elevated abundances of large parrotfishes at no-take sites in the Florida Keys, as trap fishing has been banned there since 1980 (Bohnsack et al. 1989).

Still, we cannot discount the role that piscivores may play in controlling grazing on seagrasses. Large differences in grazing intensity between regions could have 
been the result of regional differences in piscivore abundance, especially of great barracuda, which were twice as abundant in the lower Keys. Although not prized as a commercial fish, great barracuda are esteemed by some anglers as a game fish (Schmidt 1989). As such, this species may be impacted by fishing along reefs in the northern Florida Keys. A negative significant correlation ( $\mathrm{r}=-0.321$ ) between great barracuda density and leaf losses on tethers, coupled with the greater abundances of larger parrotfishes near reefs, suggests that predation risk (e.g. Heithaus et al. 2002, Preisser et al. 2005) may limit large parrotfishes to feeding in seagrasses adjacent to reefs in the lower Keys. Perhaps this explains why we did not detect a strong relationship between large parrotfish density and the proportion of shoots attacked by them. Still, the modest correlation between tether losses and densities of great barracuda estimated from point counts shows that if risk of predation plays a role in determining grazing intensity on seagrasses surrounding the reefs of the lower Keys, it is not a major one. A recent evaluation of Caribbean reef food webs concluded that strong interactions between adjacent trophic levels are rare (Bascompte et al. 2005). As such, strong top-down restrictions on the transfer of seagrass production via the grazing pathway are likely to be rare.

Based on reviews that documented higher densities of exploited piscivores in marine protected areas (Halpern \& Warner 2002, Halpern 2003) and more specific regional studies that found higher densities of targeted piscivores on protected reefs in the Florida Keys (e.g. Sluka et al. 1994), we anticipated recording greater abundances of these predators at the no-take sites than at fished sites. Instead, the piscivore guild was dominated by moderately fished, transient predators (jacks and great barracuda) rather than heavily fished snappers and groupers. Given that historical data on these species are lacking (cf. Edgar \& Barrett 1999), and the fact that persistent intense commercial fishing throughout the Keys pre-dated the early 1900s when investigations began (Viele 2001), it is uncertain if the conditions described in the present study at protected sites are representative of reef food webs in earlier times (Knowlton 2004). It is noteworthy, however, that Hixon \& Carr (1997) also found transient predators (bar jacks), and not snappers and groupers, to be the dominant piscivores at Lee Stocking Island, Bahamas, where fishing pressure was reported to be low.

It may also be that methodological artifacts (e.g. diver avoidance or short survey duration) led to low incidences of targeted piscivores at no-take sites (Kulbicki 1998, Edgar et al. 2004). Moreover, while some piscivores tend to be widely dispersed, others actively seek shelter within the reef matrix and would not be detected without the use of a roving diver technique
(Colin 1996, Kulbicki 1998). Still, both point counts and belt transect surveys have been successfully used to document the benefits of establishing no-take zones elsewhere (Edgar \& Barrett 1999). Thus, it seems that exploited species (both piscivores and omnivores) are truly more abundant at the no-take sites than at the fished sites. It is also possible that targeted piscivores were abundant in these seagrass habitats at night and were missed during our surveys (Eggleston et al. 1998), although another study addressing a separate question at our lower Keys study sites found smaller barjacks to be the only piscivore present during nocturnal fish surveys (Blackmon 2005).

In conclusion, while the lack of effect of fishing pressure on densities of large piscivores was unexpected, we found some evidence that the anticipated increases in regional densities of piscivorous fishes were associated with regional differences in grazing intensity by parrotfishes. We also found that while grazing intensity on seagrasses varied greatly, significant quantities of seagrass production are reaching reef-resident consumers. Taken together with emerging evidence on the importance of allochthonous inputs of nutrients for algal growth, it seems clear that the existing paradigm of coral reef food webs as tightly coupled, recycling networks requires re-examination. It is also clear that more detailed quantification of cross-habitat energy exchanges is needed to validate existing food web models. Among the important consequences of such validation will be the ability to provide data-based landscape recommendations for establishing 'marine protected area' designs.

Acknowledgements. The development of these ideas was supported by grants from University of North Carolina at Wilmington National Undersea Research Center (UNCW No. 9537), The Nature Conservancy's Ecosystem Research Program and Marine Fisheries Initiative Program (MARFIN). We also express our appreciation to Drs. J. Bohnsack, B. Causey, B. Keller, and S. Miller, and UNCW Captains K. Boykin and O. Rutten for providing us with a historical background on fishing and the establishment of marine reserves in the Florida Keys National Marine Sanctuary. Additionally, we thank Drs. R. Aronson, J. Cebriàn, S. Powers, and 4 anonymous reviewers for constructive criticisms of this work. This is MESC Contribution No. 368.

\section{LITERATURE CITED}

Ault J, Bohnsack J, Meester G (1998) A retrospective (19791996) multispecies assessment of coral reef fish stocks in the Florida Keys. Fish Bull 96:395-414

Bascompte J, Melián CJ, Sala E (2005) Interaction strength combinations and the overfishing of a marine food web. Proc Natl Acad Sci USA 102:5443-5447

Blackmon DC (2005) Diel vertical migration of seagrass-associated benthic invertebrates: a novel escape mechanism that provides an allochthonous input of seagrass-based 
production to coral reef resident predators, $\mathrm{PhD}$ dissertation, University of South Alabama, Mobile

Bohnsack JA, Bannerot SP (1986) A stationary visual census technique for quantitatively assessing community structure of coral reef fishes. NOAA Tech Rep NMFS 41

Bohnsack JA, Sutherland DL, Harper DE, McClellan DB, Hulsbeck MW, Holt CM (1989) The effects of fish trap size on reef fish catch off southeastern Florida. Mar Fish Rev 51:36-46

Bohnsack JA, Harper DE, McClellan DB (1994) Fisheries trends from Monroe County, Florida. Bull Mar Sci 54:982-1018

Cadenasso ML, Pisckett STA, Bell SS, Benning TL, Carreiro MM, Dawson TE (2003) An interdisciplinary and synthetic approach to ecological boundaries. BioScience 53: 717-722

Clark JR, Causey B, Bohnsack JA (1989) Benefits from coral reef protection: Looe Key Reef, Florida. In: Magoon HCOT, Minor D, Tobin LT, Clark D (eds) Coastal zone '89 American Society of Civil Engineers, New York, Charleston, SC, p 3076-3086

Clarke K (1993) Non-parametric multivariate analyses of changes in community structure. Aust J Ecol 18:117-143

Clifton KE, Robertson DR (1993) Risks of alternative mating tactics. Nature 366:520

Colin PL (1996) Longevity of some coral reef fish spawning aggregations. Copeia 1996:189-191

Dunne JA, Williams RJ, Martinez ND (2004) Network structure and robustness of marine food webs. Mar Ecol Prog Ser 273:291-302

Edgar G, Barrett N (1999) Effects of the declaration of marine reserves of Tasmanian reef fishes, invertebrates, and plants. J Exp Mar Biol Ecol 242:107-144

Edgar GJ, Bustamante RH, Fari JM, Calvopi M, Martinez NA, Toral-Granda MV (2004) Bias in evaluating the effects of marine protected areas: the importance of baseline data for the Galápagos Marine Reserve. Environ Conserv 31: $212-218$

Eggleston DB, Grover JJ, Lipcius RN (1998) Ontogenetic diet shifts in Nassau grouper: trophic linkages and predatory impacts. Bull Mar Sci 63:111-126

Fioravanti G, Valentine JF (2007) Impacts of reef architecture and fishing on food webs in back reef environments of the upper Florida Keys national marine sanctuary. Fla Sci (in press)

Halpern BS (2003) The impact of marine reserves: do reserves work and does reserve size matter? Ecol Appl 13:117-137

Halpern BS, Warner RR (2002) Marine reserves have rapid and lasting effects. Ecol Lett 5:361-366

Hatcher B (1997) Coral reef ecosystems: how much greater is the whole than the sum of the parts? Proc 8th Int Coral Reef Symp 1:43-56

Hay ME (1981) Spatial patterns of grazing intensity on a Caribbean barrier reef: herbivory and algal distribution. Aquat Bot 11:97-109

Heithaus MR, Dill LM, Marshall GJ, Buhleier B (2002) Habitat use and foraging behavior of tiger sharks (Galeocerdo cuvier) in a seagrass ecosystem. Mar Biol 140:237-248

Hilderbrand GV, Hanley TA, Robbins CT, Schwartz CC (1999) Role of brown bears (Ursus arctos) in the flow of marine nitrogen into a terrestrial ecosystem. Oecologia 121:546-550

Hixon MA, Carr MH (1997) Synergistic predation, density dependence, and population regulation in marine fish. Science 277:946-949

Kirkman H, Reid D (1979) A study of the role of seagrass Posidonia australis in the carbon budget of an estuary. Aquat Bot 7:173-183
Kirsch KD, Valentine JF, Heck KL (2002) Parrotfish grazing on turtlegrass Thalassia testudinum: evidence for the importance of seagrass consumption in food web dynamics of the Florida Keys National Marine Sanctuary. Mar Ecol Prog Ser 227:71-85

Knowlton N (2004) Multiple stable states and the conservation of marine ecosystems. Prog Oceanogr 60:387-396

Kulbicki M (1998) How acquired behavior of commercial reef fishes may influence the results obtained from visual censuses. J Exp Mar Biol Ecol 222:11-30

Leichter J, Stewart HL, Miller SL (2003) Episodic nutrient transport to Florida coral reefs. Limnol Oceanogr 48: $1394-1407$

Link J (2002) Does food web theory work for marine ecosystems? Mar Ecol Prog Ser 230:1-9

Macintyre IG, Graus RR, Reinthal PN, Littler MM, Littler DS (1987) The barrier reef sediment apron: Tobacco Reef, Belize. Coral Reefs 6:1-12

McAfee ST, Morgan SG (1996) Resource use by five sympatric parrotfishes in the San Blas Archipelago, Panama. Mar Biol 125:427-437

McClanahan T (1998) Predation and the distribution and abundance of tropical sea urchin populations. J Exp Mar Biol Ecol 218:231-255

McClanahan T, Graham NAJ (2005) Recovery trajectories of coral reef fish assemblages in Kenyan marine protected areas. Mar Ecol Prog Ser 294:241-248

McClanahan T, Mangi S (2000) Spillover of exploitable fishes from a marine park and its effect on the adjacent fishery. Ecol Appl 10:1792-1805

McClanahan TR, Kamukuru AT, Muthiga NA, Gilagabher M, Obura D (1995) Effect of sea urchin reductions on algae, coral, and fish populations. Conserv Biol 10:136-154

Mumby PJ, CP Dahlgren, AR Harborne, CV Kappel and 10 others (2006) Fishing, trophic cascades, and the process of grazing on coral reefs. Science 311:98-101

Myers R, Worm B (2003) Rapid worldwide depletion of predatory fish communities. Nature 423:280-283

Nakano S, Murakami M (2001) Reciprocal subsidies: dynamic interdependence between terrestrial and aquatic food webs. Proc Natl Acad Sci USA 98:166-170

Ogden JC, Zieman JC (1977) Ecological aspects of coral reef-seagrass bed contacts in the Caribbean. Proc 3rd Int Coral Reef Symp:377-382

Ogden JC, Brown R, Salesky N (1973) Grazing by the echinoid Diadema antillarum: formation of halos around West Indian patch reefs. Science 182:715-717

Pandolfi JM, Bradbury RH, Sala E, Hughes TP and 8 others (2003) Global trajectories of the long-term decline of coral reef ecosystems. Science 301:955-958

Polis G, Strong D (1996) Food web complexity and community dynamics. Am Nat 147:813-846

Powers ME (2001) Prey exchange between a stream and its forested watershed elevates predator densities in both habitats. Proc Natl Acad Sci USA 98:14-15

Preisser EL, Bolnick DI, Benard MF (2005) Scared to death? The effects of intimidation and consumption in predatorprey interactions. Ecology 86:501-509

Randall JE (1965) Grazing effect on sea grasses by herbivorous reef fishes in the West Indies. Ecology 46:255-260

Randall JE (1967) Food habits of reef fishes of the West Indies. Stud Trop Oceanogr 5:665-847

Roberts C, Bohnsack JA, Gell F, Hawkins JP, Goodridge R (2001) Effects of marine reserves on adjacent fisheries. Science 294:1920-1923

Russ GR, Alcala AC (2004) Marine reserves: long-term protection is required for full recovery of predatory fish 
populations. Oecologia 138:622-627

Sale PF, Douglas W (1981) Precision and accuracy of visual census technique for fish assemblages on coral patch reefs. Environ Biol Fish 6:333-339

Schmidt TW (1989) Food habits, length-weight relationship and condition factor of young great barracuda, Sphyraena barracuda (Walbaum), from Florida Bay, Everglades National Park, Florida. Bull Mar Sci 44:163-170

Shipp RL (2003) A perspective on marine reserves as a fishery management tool. Fish Res 28:12-21

Sluka R, Chiappone M, Sullivan KM (1994) Comparison of juvenile grouper populations in southern Florida and the central Bahamas. Bull Mar Sci 54:871-880

Editorial responsibility: Otto Kinne (Editor-in-Chief), Oldendorf/Luhe, Germany
Underwood AJ (1981) Techniques and analysis of variance in experimental marine biology and ecology. Oceanogr Mar Biol Annu Rev 19:513-605

Valentine JF, Duffy JE (2006) The central role of grazing in seagrass ecology. In: Larkum AWD, Orth RJ, Duarte CM (eds) Seagrass: biology, ecology and their conservation. Kluwer Academic Publishers, Dordrecht p 463-501

Valentine JF, Heck KL (2005) Interaction strength at the coral reef-seagrass interface: has overfishing diminished the importance of seagrass habitat production for coral reef food webs? Coral Reefs. 24:209-213

Viele J (2001) The Florida Keys. Vol 1. A history of the pioneers. Pineapple Press, Sarasota, FL

Submitted: September 21, 2005; Accepted: July 3, 2006

Proofs received from author(s): February 19, 2007 